\title{
TIM-4 blockade of KCs combined with exogenous TGF- $\beta$ injection helps to reverse acute rejection and prolong the survival rate of mice receiving liver allografts
}

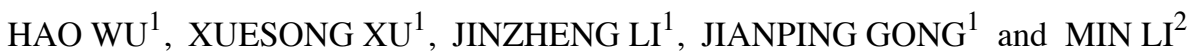 \\ ${ }^{1}$ Department of Hepatobiliary Surgery, Second Affiliated Hospital of Chongqing Medical University, Chongqing 400010; \\ ${ }^{2}$ Department of Hepatobiliary Surgery, Suining Central Hospital, Suining, Sichuan 629099, P.R. China
}

Received June 19, 2017; Accepted March 23, 2018

DOI: $10.3892 /$ ijmm.2018.3606

\begin{abstract}
An acute reaction response (AR) following liver transplantation (LT) is caused by immune responses that are primarily mediated by $\mathrm{T}$ lymphocytes. Kupffer cells (KCs) are the largest antigen presenting cell (APC) group in vivo and are the primary modulators of the inflammatory or tolerogenic immune response in liver tissues. T cell immunoglobulin-domain and mucin-domain-4 (TIM-4), the only TIM protein not expressed on T cells, is expressed on APCs; suggesting that it mediates the various immune responses. However, to the best of our knowledge, the role of TIM-4 expressed by KCs in LT injury remains unknown. The present study aimed to explore whether and how TIM-4 expressed by $\mathrm{KCs}$ is involved in the AR of liver allografts. Orthotopic liver transplantation (OLT) was performed in mice to establish a
\end{abstract}

Correspondence to: Dr Jianping Gong, Department of Hepatobiliary Surgery, Second Affiliated Hospital of Chongqing Medical University, 76 Linjiang Street, Chongqing 400010, P.R. China

E-mail: gongjianping11@126.com

Professor Min Li, Department of Heptaobiliary Surgery, Suining Central Hospital, 127 Deshengxi Road, Suining, Sichuan 629099, P.R. China

E-mail:wuhao_48@126.com

Abbreviations: TIM-4, T cell immunoglobulin and mucin domain-4; KCs, kupffer cells; APCs, antigen presenting cells; OLT, orthotopic liver transplantation; LT, liver transplantation; AR, acute rejection; Treg, T regulatory cell; NF- $\kappa \mathrm{B}$, nuclear factor- $\kappa \mathrm{B}$; MAPK, mitogen-activated protein kinase; TGF- $\beta$, transforming growth factor- $\beta$; IL-4, interleukin-4; STAT6, signal transducer and activator of transcription 6; Gata3, transcription factor gata3; DCs, dendritic cells; AST, aspartate aminotransferase; ALT, alanine aminotransferase; TBIL, total bilirubin in serum; TNF- $\alpha$, tumor necrosis factor- $\alpha$; IFN- $\gamma$, interferon- $\gamma$

Key words: liver transplantation, kupffer cells, $\mathrm{T}$ cell immunoglobulin-domain and mucin-domain-4, acute reaction response, transforming growth factor- $\beta$, T regulatory cell model of AR and results demonstrated that LT may lead to the augmented expression of TIM-4 in activated KCs. It was also revealed that TIM-4 blockade markedly attenuated AR injury in vivo via the nuclear factor- $\kappa \mathrm{B}(\mathrm{NF}-\kappa \mathrm{B})$ and $\mathrm{p} 38$ mitogen-activated protein kinase (p38 MAPK) signaling pathways. In addition, levels of transforming growth factor- $\beta$ (TGF- $\beta$ ) were increased following TIM- 4 blockade. Furthermore, in a KC/cluster of differentiation (CD) $4^{+} \mathrm{T}$ cell co-culture system, blocking TIM-4 inhibited T helper 2 (Th2) differentiation, stimulated the conversion of naive (CD) $4^{+}$ $\mathrm{T}$ cells into $\mathrm{CD} 4^{+} \mathrm{CD} 25^{+}$Forkhead box protein $\mathrm{p} 3^{+} \mathrm{T}$ regulatory cells and suppressed interleukin-4/signal transducer and activator of transcription 6/transcription factor gata3 signaling. These effects were enhanced following the addition of TGF- $\beta$. It was also demonstrated that LT mouse models treated with TIM-4 blockade in combination with exogenous TGF- $\beta$ injections, increased the survival times of mice and enhanced the amelioration of AR in LT. These results indicate that blocking the expression of TIM- 4 by KCs via exogenous TGF- $\beta$ injection may be an effective therapeutic strategy to inhibit the AR of liver allografts.

\section{Introduction}

Orthotopic liver transplantation (OLT) is an effective method of treating advanced liver disease; however, immune rejection following transplantation remains a major clinical problem (1). Patient outcomes following liver transplantation (LT) have markedly improved due to the extensive use of immunosuppressants. However, patients may experience severe side effects and acute rejection (AR) following LT, which may consequently reduce their quality of life $(1,2)$.

It has been determined that AR following LT is a local cellular immune responses primarily mediated by $\mathrm{T}$ lymphocytes (3). Therefore, the number and functional balance of T cell subsets [T helper (Th) 1/2; Th17 and T regulatory (Treg) cells] is associated with the acquisition of immune tolerance. $\mathrm{T}$ cell immunoglobulin and mucin domain (TIM) genes, a novel family of co-stimulatory molecules, are critical in determining the activation and differentiation of Th cells (4). The TIM family of cell surface proteins consists of eight members in mice (TIM 1-8) and three in humans (TIM 1, 3 and 4) (5). 
All TIM family protein members are type I cell surface glycoproteins and each possesses a common immunoglobulin (Ig) V-like domain, a mucin-like domain, a single transmembrane domain and a cytoplasmic region $(5,6)$. Previous studies have implicated TIM in the mediation of certain immune responses, including autoimmunity, transplant tolerance, allergic diseases and response to viral infections (5-7). TIM-4 is the only non-T cell TIM protein and is solely expressed on antigen presenting cells (APCs), particularly in macrophages and cluster of differentiation (CD) $11 \mathrm{c}^{+}$dendritic cells (DCs). TIM-4 signals have been identified in activated human $\mathrm{T}$ cells, including the $\mathrm{CD}^{+}{ }^{+}$and $\mathrm{CD} 8^{+} \mathrm{T}$ cells $(8)$. TIM- 4 was initially identified as a phosphatidylserine (PS) receptor, functioning to mediate the binding and engulfment of apoptotic bodies, which is a crucial step in phagocytosis and innate immune reactions. By acting as a TIM-1 ligand on T cells, TIM-4 may function as a co-stimulatory molecule that regulates the adaptive immune response $(5,8,9)$. It has been indicated that the interaction between TIM-4 and TIM-1 suppresses peripheral immune tolerance and activates T cells (10). In addition, TIM-4 is able to bind to naive $\mathrm{CD} 4^{+} \mathrm{T}$ cells in the absence of surface TIM- 4 expression $(9,10)$, suggesting that an alternative unidentified receptor is present on $\mathrm{CD}^{+}{ }^{+} \mathrm{T}$ cells. However, the specific effect of TIM-4 co-stimulation on $\mathrm{T}$ cell activation in vivo remains unclear. In vitro studies using TIM-4-immunoglobulin fusion proteins have presented conflicting results: TIM-4 signaling increases the proliferation of activated $\mathrm{T}$ cells but has the opposite effect on naive T cells $(9,11,12)$.

Kupffer cells (KCs) are the largest group of APCs in vivo and account for $10-15 \%$ of total liver cells. They also account for $80-90 \%$ of all monocyte-marophage cells and exhibit high expression of TIM-4 (13). KCs affect various processes, including antigen presentation, the secretion of cytokines and immune regulation in patients following LT (13). It has been demonstrated that blocking TIM-4 expression in mice impairs the intrinsic function of macrophages to phagocytose $\mathrm{PS}^{+}$hepatic debris, which further mitigates toll like receptor (TLR)-4-mediated inflammation in liver ischemia-reperfusion injury (14). Blocking TIM-4 expression in DCs initiates the production of induced (i) Tregs, which are able to markedly prolong the survival of mice that have undergone a skin allograft (15). Current understanding regarding the action of TIM-4 is limited to its involvement in immune tolerance; to the best of our knowledge, no studies have assessed the effects of TIM-4 on rejection following LT.

The present study demonstrated that OLT enhances TIM-4 expression in liver KCs. It was assessed whether blocking TIM-4 expression in KCs attenuates hepatic injury and inhibits the inflammatory response. Additionally, naive $\mathrm{CD} 4^{+}$ $\mathrm{T}$ cells differentiation were directed to induce the generation of potent and functionally suppressive iTregs by impeding interleukin (IL)-4/signal transducer and activator of transcription 6 (STAT6) signaling. It was also evaluated whether blocking TIM-4 expression increases levels of transforming growth factor- $\beta$ (TGF- $\beta$ ), which may stimulate the expansion of iTregs. The results of the current study demonstrated that blocking TIM-4 expression and administering exogenous TGF- $\beta$ following LT markedly increases the de novo induction of iTregs from naive $\mathrm{CD}^{+} \mathrm{T}$ cells, thus attenuating $\mathrm{AR}$ and promoting the survival of mice following LT.

\section{Materials and methods}

Experimental animals. A total of 40 8-10 week old wild-type female C57BL/6 mice weighing 16-22 g and 50 8-10 week female $\mathrm{C} 3 \mathrm{H}$ mice weighing 16-22 $\mathrm{g}$ were purchased from the Animal Experimental Center of Chongqing Medical University (Chongqing, China). All mice were housed at a temperature of $23^{\circ} \mathrm{C}$ and humidity of $60 \%$ under a 12-h light/dark cycle. Food and water were supplied ad libitum. All protocols involving mice were conducted in accordance with the Guide for the Care and Use of Laboratory Animals published by the US National Institutes of Health (16) and all experiments were approved by the Animal Care and Use Committee of Second Affiliated Hospital of Chongqing Medical University (Chongqing, China).

OLT. An improved Kamada's two-cuff method with minor modifications was used to perform OLT between female $\mathrm{C} 57 \mathrm{BL} / 6$ donor mice and inbred female $\mathrm{C} 3 \mathrm{H}$ recipient mice, as previously described (17). Donor and recipient mice received $1.9 \%$ ethyl ether anesthesia via nostril cannula. The use of ethyl ether was approved by the Animal Experimental Centre of Chongqing Medical University (Chongqing, China). Warm ischemia, cold ischemia and anhepatic times were set at $0 \mathrm{~min}$, $1 \mathrm{~h}$ and $20 \mathrm{~min}$ respectively. Only $\mathrm{C} 3 \mathrm{H}$ recipient mice underwent the following experiments. $\mathrm{C} 3 \mathrm{H}$ mice that had undergone single LT from donor mice but had not received subsequent treatments $(n=5)$ were sacrificed 24,48 and $72 \mathrm{~h}$ following surgery to determine KC activity and TIM- 4 expression in the liver. Recipient mice $(n=30)$ were then randomly divided into 3 treatment groups: A sham group $(n=10)$ that did not receive a transplant but still underwent abdominal cutting and vascular exposures around the liver; a control mouse monoclonal antibody (mAb) group ( $\mathrm{n=10}$; cat. no. GTX14149; 1:50 dilution; $\mathrm{mAb}$ received from GeneTex, Inc., Irvine, CA, USA) treated with $0.35 \mathrm{mg} / \mathrm{mouse} \mathrm{mAb}$ via portal vein injection to establish an LT model; and a T cell immunoglobulin mucin protein 4 (TIM-4) mAb group $(n=10)$ that received $0.35 \mathrm{mg} / \mathrm{mouse}$ portal vein injections. The indicated treatments and dosages in each group were administered intravenously for 2 days following surgery at $24 \mathrm{~h}$ intervals. On day 7 following surgery, all mice were anaesthetized via inhaled $1.9 \%$ ethyl ether and $0.5 \mathrm{ml} /$ mouse blood samples were drawn from the abdominal aorta. Mice were then sacrificed in a sealed-container with an overdose of carbon dioxide $\left(\mathrm{CO}_{2}\right.$ replacement rate: $20 \%$ of the container volume/min). Murine liver tissues were subsequently removed and examined and $\mathrm{KCs}$ were then isolated.

Another mouse model was then established. Donor mice were injected with clodronate liposomes (CL; $10 \mathrm{mg} / \mathrm{kg}$; cat. no. 40337ES05/10; Shanghai Yeasen Biotechnology Co., Ltd., Shanghai, China) via the caudal vein to destroy liver $\mathrm{KCs} 24 \mathrm{~h}$ prior to surgery. Following CL pretreatment, OLT or sham surgery was performed $(\mathrm{C} 57 \mathrm{BL} / 6 \rightarrow \mathrm{C} 3 \mathrm{H})$ and recipient $\mathrm{C} 3 \mathrm{H}$ mice were administered the aforementioned treatments. Recipient mice were randomly divided into CL+sham, $\mathrm{CL}+$ control $\mathrm{mAb}$ and CL+TIM-4 mAb groups (all $\mathrm{n}=5$ ). All recipient mice were sacrificed and underwent tissue section examination 7 days post-surgery.

Cell isolation and purification. OLT or sham surgery was performed and KCs were isolated. A modified method of the 
in vitro type IV collagenase digestion was used to dissociate liver tissue. Mice were anaesthetized using inhaled $1.9 \%$ ethyl ether. Murine heartbeats and thoracic breathing were monitored to ensure that mice were anesthetized and not sacrificed. The liver was perfused in situ with $10 \mathrm{ml} \mathrm{PBS}(3 \mathrm{ml} / \mathrm{min})$ at $37^{\circ} \mathrm{C}$ to remove red blood cells. Liver tissues were then dispersed in RPMI-1640 (Gibco; Thermo Fisher Scientific Inc., Waltham, MA, USA) containing $0.5 \%$ type IV collagenase (Sigma-Aldrich; Merck KGaA, Darmstadt, Germany) at $37^{\circ} \mathrm{C}$ for $30 \mathrm{~min}$. Liver homogenate was filtered through a 200 -mesh sieve to remove undigested tissue and non-parenchymal cells of the liver were obtained using the gradient centrifugation method. The cell suspension was centrifuged at $300 \mathrm{x} g$ on an 5810R machine (Eppendorf, Hamburg, Germany) for $5 \mathrm{~min}$ at $4^{\circ} \mathrm{C}$. The top aqueous phase was discarded and the cell sediment was reserved. Cell sediments were then resuspended with $10 \mathrm{ml} \mathrm{RPMI}-1640$ and centrifuged at $300 \mathrm{x} \mathrm{g}$ for $5 \mathrm{~min}$ at $4^{\circ} \mathrm{C}$, the top aqueous phase was discarded and cell sediments were reserved. Cell sediments were then resuspended with $10 \mathrm{ml}$ RPMI-1640 and centrifuged at $50 \times \mathrm{g}$ for $3 \mathrm{~min}$ at $4^{\circ} \mathrm{C}$. The top aqueous phase (cleared cell suspension) was transferred into a new $10 \mathrm{ml}$ centrifuge tube and centrifuged at $300 \mathrm{x} \mathrm{g}$ for $5 \mathrm{~min}$ at $4^{\circ} \mathrm{C}$, the top aqueous phase was discarded and cell sediments were reserved. To further purify $\mathrm{KCs}$, the selective adherence to plastic method was used following the protocol described by Li et al (18). Cells were seeded in a 6-well plate at a density of $1-3 \times 10^{7} /$ well in Dulbecco's Modified Eagle's medium supplemented with $10 \%$ fetal bovine serum (both HyClone, GE Healthcare Life Sciences, Logan, UT, USA) and $100 \mathrm{U} / \mathrm{ml}$ penicillin/streptomycin (Sigma-Aldrich; Merck $\mathrm{KGaA}$ ) and incubated for $2 \mathrm{~h}$ in a $5 \% \mathrm{CO}_{2}$ atmosphere at $37^{\circ} \mathrm{C}$. Following washing with PBS, non-adherent cells were removed from the dish; adherent cells were KCs.

Naive $\mathrm{CD} 4^{+} \mathrm{CD} 25^{-} \mathrm{T}$ cells were isolated using the $\mathrm{CD} 4^{+}$ $\mathrm{T}$ cell isolation kit II and CD25 microbeads (both Miltenyi Biotec GmbH, Bergisch Galdbach, Germany) were utilized to select the CD25- population.

Immunohistochemistry. Liver tissues were fixed with $10 \%$ formaldehyde at room temperature for $4 \mathrm{~h}$ and subsequently embedded in paraffin. Paraffinized sections were placed in an oven at $58^{\circ} \mathrm{C}$ for $2 \mathrm{~h}$, dewaxed with xylene, placed in $100 \%$ ethanol and rehydrated using 90-70\% ethanol for $3 \mathrm{~min}$ at each stage. Sections were washed with PBS three times ( $3 \mathrm{~min} / \mathrm{wash}$ ), placed in a $0.01 \mathrm{M}$ sodium citrate antigen retrieval solution $\left(\mathrm{pH} 6.0,95^{\circ} \mathrm{C}\right.$ ) for $15 \mathrm{~min}$ and then cooled for $15 \mathrm{~min}$ at room temperature. Sections were washed with PBS three times ( $3 \mathrm{~min} /$ wash), treated with $4.3 \% \mathrm{H}_{2} \mathrm{O}_{2}$ to block endogenous peroxidase for $20 \mathrm{~min}$ at room temperature. Sections were washed with PBS three times ( $3 \mathrm{~min} /$ wash) and then blocked with $10 \%$ fetal calf serum (FCS; cat. no. 25-01860; Shanghai Biomart Technology, Co., Ltd, Shanghai, China) for $30 \mathrm{~min}$ at room temperature. Sections were washed with PBS three times (3 min/wash) and incubated with anti-CD163 (EPR19; cat. no. ab182422; 1:100 dilution; Abcam, Cambridge, MA, USA) overnight at $4^{\circ} \mathrm{C}$. Sections were washed with PBS three times ( $3 \mathrm{~min} /$ wash) and incubated with biotin-conjugated goat anti-rabbit and goat anti-mouse immunoglobulin G secondary antibodies (cat. nos., BA1003 and BA1001, respectively; Wuhan Boster Biological Technology, Ltd., Wuhan; China) at $37^{\circ} \mathrm{C}$ for $90 \mathrm{~min}$. Sections were washed with PBS three times (3 $\mathrm{min} /$ wash), treated with 3,3'-diaminobenzidine for $5 \mathrm{~min}$ at room temperature, stained with hematoxylin for $30 \mathrm{sec}$ at room temperature and treated with hydrochloric acid for $1 \mathrm{sec}$. Sections were then placed in $70 \%$ ethanol for $3 \mathrm{~min}$ and then treated with $80-100 \%$ ethanol for 3 min each. Following dehydration, sections were mounted, observed using a XSP-13C-LB microscope (Shanghai Precision \& Scientific Instrument Co., Ltd., Shanghai, China) at a magnification of x400 and analyzed using Image pro plus 6.0 (Media Cybernetics, Inc., Rockville, MD, USA).

Immunostaining. KCs derived from recipient (sham, control $\mathrm{mAb}$ or TIM- $4 \mathrm{mAb}$ mice) were collected and were fixed in $4 \%$ paraformaldehyde for $1 \mathrm{~h}$ at room temperature. Slides were washed with PBS three times ( $3 \mathrm{~min} /$ wash) and blocked with $30 \mathrm{~min}$ in $10 \% \mathrm{FCS}$ at room temperature. Slides were then washed with PBS three times ( $3 \mathrm{~min} /$ wash) and incubated with TIM-4 antibodies (RMT4-53, cat. no. GTX14149; 1:100 dilution; GeneTex Inc.) overnight at $4^{\circ} \mathrm{C}$. Slides were washed with PBS three times ( $3 \mathrm{~min} / \mathrm{wash}$ ) and incubated with specific secondary antibodies labeled with tetramethylrhodamine (red; 1:100 dilution; cat. no. GMS40036; Bio Valley, Shanghai; China) or DAPI (blue) for $30 \mathrm{~min}$ at room temperature. Slides were then washed with PBS three times ( $3 \mathrm{~min} /$ wash) and sealed with FluorFluoromount-G ${ }^{\mathrm{TM}}$ Slide Mounting medium (Southern Biotech, Birmingham, AL, USA). Images were taken using a Zeiss LSM 510 confocal microscope (magnification x800; Zeiss AG, Thornwood, NY, USA) and were analyzed using an Image Analysis system, version 11.0 (Chang Heng Rong Technology Co., Ltd., Beijing; China).

Western blot analysis. Cells or liver homogenates were lysed in lysis buffer (Gibco; Thermo Fisher Scientific, Inc.) and the concentration of total protein was determined using a BCA Protein assay kit (Sangon Biotech Co., Ltd., Shanghai, China). A total of $40 \mu \mathrm{g}$ protein was loaded per lane, separated using 12\% SDS-PAGE gel and then electrotransferred onto polyvinylidene difluoride membranes (Bio-Rad Laboratories Inc., Hercules, CA, USA). Membranes were blocked using $5 \%$ non-fat milk in Tris-buffered-saline with Tween at room temperature for $1 \mathrm{~h}$ and incubated with primary antibodies overnight at $4^{\circ} \mathrm{C}$. The primary antibodies used included: TIM-4 (RMT4-53, cat. no. GTX14149; 1:100 dilution; GeneTex Inc.), tumor necrosis factor- $\alpha$ (TNF- $\alpha$; 52B38, cat. no. ab1793; $1: 100$ dilution; Abcam), interferon- $\gamma$ (IFN- $\gamma$; \#37895R, cat. no. MAB485R; 1:100 dilution; R\&D Systems Inc., Minneapolis, MN, USA), chemokine ligand 2 (CCL2; 2D8, cat. no. GTX60582; 1:100 dilution; GeneTex Inc.), C-X-C motif chemokine ligand 2 (CXCL2; cat. no. GTX74085; 1:200 dilution; GeneTex Inc.), TGF- $\beta$ (cat. no. ab92486; 1:100 dilution), phosphorylated (p)-signal transducer and activator of transcription 6 (STAT6; phospho Y641, cat. no. ab28829; 1:100 dilution), p-p65 (phospho S536, cat. no. ab86299; 1:100 dilution), p-p38 (phospho Y182, cat. no. ab47363; 1:100 dilution), forkhead box P3 (Foxp3; 236A/E7, cat. no. ab20034; 1:100 dilution), transcription factor gata3 (Gata3; cat. no. ab106625, $1: 100$ dilution) and $\beta$-actin (cat. no. ab8226; 1:100 dilution) (all from Abcam). Membranes were then washed with TBS-Tween-20 and incubated with peroxidase-conjugated 
secondary antibodies (cat. nos. A0545, A9044; 1:8,000 dilution; Sigma-Aldrich; Merck KGaA) at room temperature for $1 \mathrm{~h}$. An enhanced chemiluminescence kit (GE Healthcare, Chicago, IL, USA) was used to perform chemiluminescence and protein bands were visualized using X-ray films. All images were analyzed using ImageJ software, version 14.8 (National Institutes of Health, Bethesda, MD, USA).

Reverse transcription quantitative polymerase chain reaction $(R T-q P C R)$. RNAs were extracted from cell lysates using TRIzol RNA-extraction reagent and reverse transcription was performed using PrimeScript ${ }^{\mathrm{TM}}$ 1st Strand cDNA Synthesis kit (cat. no. 6110A) (both from Takara Bio Inc., Otsu, Japan) following the manufacturer's protocol. qPCR assays were performed using SYBR Premix Ex Taq (Takara Bio Inc.) and a cDNA template on the Applied Biosystems 7500 Real-time PCR System (Applied Biosystems; Thermo Fisher Scientific Inc.). The primers used for qPCR amplification were as follows: TIM-4; forward, 5'-CAATCGAGGTGACAGTGGG-3' and reverse, 5'-AAGGAGCCAGGTGTTGTTG-3'; $\beta$-actin; forward, 5'-GCTCTGGCTCCTAGCACCAT-3' and reverse, 5'-GCCACCGATCCACACAGAGT-3'. qPCR was conducted in a $50 \mu \mathrm{l}$ reaction system, including $1 \mu \mathrm{l}$ forward and $1 \mu \mathrm{l}$ reverse primers, $0.5 \mu 1$ 20x SYBR-Green I, $25 \mu 1$ 2x PCR buffer, $2 \mu \mathrm{l}$ cDNA, and $20.5 \mu 1$ diethyl pyrocarbonate. The thermocycling conditions used for qPCR were as follows: $94^{\circ} \mathrm{C}$ for $4 \mathrm{~min}, 30 \mathrm{cycles}$ of $94^{\circ} \mathrm{C}$ for $20 \mathrm{sec}, 60^{\circ} \mathrm{C}$ for $30 \mathrm{sec}, 72^{\circ} \mathrm{C}$ for $30 \mathrm{sec}$, and $72^{\circ} \mathrm{C}$ for $5 \mathrm{~min}$. Each individual sample was run in triplicate and the level of expression was quantified using the comparative cycle threshold $(\mathrm{Cq})$ method. Results were normalized to $\beta$-actin expression and RNA enrichments were calculated using the $2^{-\Delta \Delta \mathrm{Cq}}$ method (19).

Carboxyfluorescein succinimidyl ester (CFSE) assay. Splenic $\mathrm{CD} 4^{+} \mathrm{T}$ cells were purified from recipient mice that had received single LT with no treatment $(n=5)$. Cells were labeled with $5 \mu \mathrm{M}$ CFSE (cat. no. 65-0850-84; eBioscience; Thermo Fisher Scientific, Inc.) for $20 \mathrm{~min}$ at $37^{\circ} \mathrm{C}$ in the dark. Cold RPMI-1640 medium was then added and cells were incubated on ice for $5 \mathrm{~min}$. $\mathrm{CD} 4^{+} \mathrm{T}$ cells were then co-cultured with TIM- $4^{+} \mathrm{KCs}$ (1:1). The following 5 experimental groups were constructed: The control group of cells that were untreated; the control $\mathrm{mAb}$ group of cells that were treated with control $\mathrm{mAb}(0.5 \mu \mathrm{g} / \mathrm{ml}, 500 \mu \mathrm{l})$; the TGF- $\beta$ group of cells that were treated with additional exogenous TGF- $\beta$ ( $1 \mathrm{ng} / \mathrm{ml}, 100 \mu \mathrm{l}$ ) following co-culture; the TIM-4 mAb group of cells that were treated with TIM-4 mAb $(0.5 \mu \mathrm{g} / \mathrm{ml}, 500 \mu \mathrm{l})$; and the TGF- $\beta+$ TIM- 4 mAb group of cells that were treated with exogenous TGF- $\beta$ and TIM- 4 mAb. All cells were co-cultured for $96 \mathrm{~h}$ at $37^{\circ} \mathrm{C}$. Following washing, cells were re-suspended in RPMI-1640 medium with $10 \%$ fetal bovine serum and then blocked with $10 \% \mathrm{FCS}$ for $30 \mathrm{~min}$ at room temperature. Cells were then stained with APC-CD4 antibodies (cat. no. GK1.5, 1:100 dilution; eBioscience; Thermo Fisher Scientific, Inc.) in the dark for $30 \mathrm{~min}$ at room temperature, centrifuged at $3,000 \mathrm{x} \mathrm{g}$ for $10 \mathrm{~min}$ at $4^{\circ} \mathrm{C}$ and resuspended twice in PBS prior to fluorescence-activated cell sorting (FACS) analysis. All experiments were performed in triplicate.

Flow cytometry. Cells (KCs or T cells) were digested for $3 \mathrm{~min}$ in $0.25 \%$ trypsin at $37^{\circ} \mathrm{C}$ and collected following centrifugation at $50 \mathrm{x} \mathrm{g}$ for $5 \mathrm{~min}$ at room temperature. Cells were then rinsed in pre-cooled PBS $\left(4^{\circ} \mathrm{C}\right)$ twice. Cells were then resuspended in $400 \mu \mathrm{l}$ binding buffer and the cell concentration was diluted to $1 \times 10^{6} / \mathrm{ml}$. Fluorochrome-labeled mAbs, including CD14-phycoerythrin (PE; cat. no. Sa2-8; 12-0141, dilution, 1:100), CD163-APC (cat. no. GHI/61; 17-1639-42, dilution, 1:100), Foxp3-PE (cat. no. 150D/E4; 12-477, dilution, 1:100), CD25-fluorescein isothiocyanate (FITC; cat. no. CD25-4E3; 11-0257, dilution, 1:100), were purchased from eBioscience; Thermo Fisher Scientific, Inc. KCs were stained for CD14 and CD163 and T cells were stained for CD25 and Foxp3 for $1 \mathrm{~h}$ at $4^{\circ} \mathrm{C}$ in the dark. Flow cytometric cell sorting was performed using FACSAria; flow cytometric data were acquired using a FACSCalibur and analyzed using Cellquest version 5.1 software (BD Biosciences, Franklin Lakes, NJ, USA). Experiments were performed in triplicate.

Detection of liver function. Cardiac puncture blood samples were collected from mice following euthanasia 7 days post-operation and allowed to clot. Serum was obtained following centrifugation at $200 \mathrm{x} \mathrm{g}$ at $4^{\circ} \mathrm{C}$ for $10 \mathrm{~min}$. Levels of aspartate aminotransferase (AST), alanine aminotransferase (ALT) and total bilirubin in serum (TBIL) were determined using a Synchron CX7 analyzer (Beckman Coulter Inc., Brea, CA, USA) in the Clinical Biochemical Laboratory of Chongqing Medical University. Experiments were performed in triplicate.

Enzyme-linked immunosorbent assay (ELISA). Liver tissues were removed from mice 7 days following surgery. Then, liver tissues were sliced and washed repeatedly with saline and formed into homogenates using a tissue crusher. Liver homogenates were then centrifuged 3 times at $300 \mathrm{xg}$ at $4^{\circ} \mathrm{C}$ for $15 \mathrm{~min}$ to obtain supernatants. TIM- $4^{+} \mathrm{KCs}$ were incubated with naive $\mathrm{CD} 4^{+} \mathrm{CD} 25^{-} \mathrm{T}$ cells for $96 \mathrm{~h}$ at $37^{\circ} \mathrm{C}$ and were then centrifuged at $300 \mathrm{x} \mathrm{g}$ at $4^{\circ} \mathrm{C}$ for $10 \mathrm{~min}$ to obtain supernatants. Levels of inflammatory cytokines in liver homogenates or supernatants were assessed using the following ELISA kits: TNF- $\alpha$ (cat. no. MAT00B), IFN- $\gamma$ (cat. no. MIF00), CCL2 (cat. no. MJE00), CXCL2 (cat. no. MM200), TGF- $\beta$ (cat. no. MB100B), IL-4 (cat. no. M4000B), IL-6 (cat. no. M6000B) and IL-13 (cat. no. M1300CB; all R\&D Systems, Inc.). All procedures were performed following the manufacturer's protocols. Absorbance was read at $450 \mathrm{~nm}$ and experiments were performed in triplicate.

Histological examination. To assess hepatic injury, liver tissues were fixed with $10 \%$ formaldehyde at room temperature for $4 \mathrm{~h}$ and then embedded in paraffin. Tissues were sliced into sections $5-\mu \mathrm{m}$ thick prior to staining with hematoxylin for $10 \mathrm{~min}$ and eosin for $3 \mathrm{~min}$ at room temperature. AR was classified into four types using the Banff schema (20).

Terminal deoxynucleotidyl transferase-mediated 2'-deoxyuridine 5'-triphosphate nick-end labeling (TUNEL) assay. Apoptotic cells were detected using a commercial TUNEL kit (cat. no. 11684817910; Roche Inc., Switzerland) following the manufacturer's protocol. The TUNEL assay was performed for paraffin-embedded sections fixed with $4 \%$ paraformaldehyde for $1 \mathrm{~h}$ at room temperature and processed following the 
A

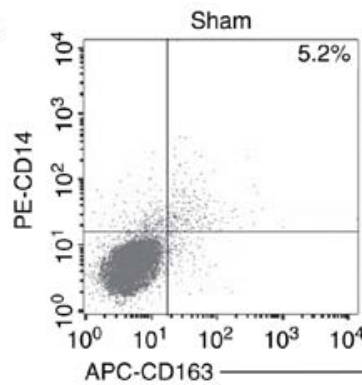

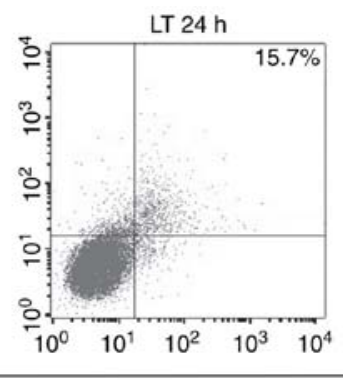
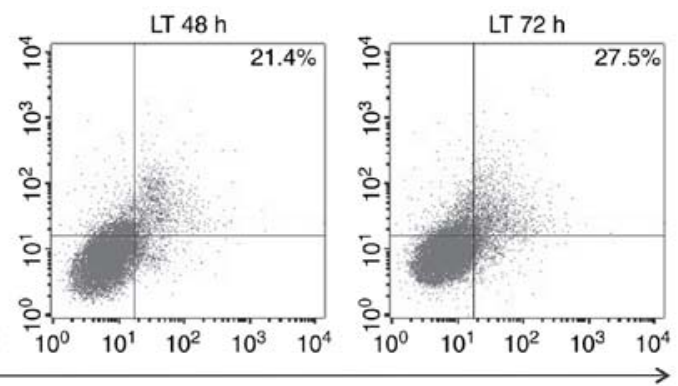

$\mathrm{B}$

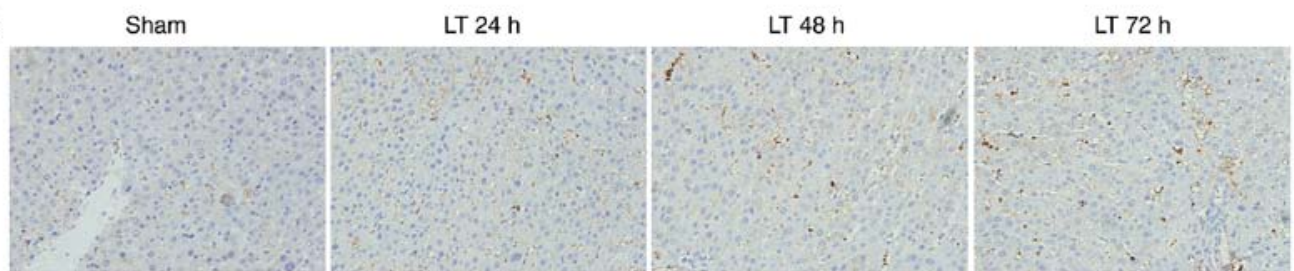

C
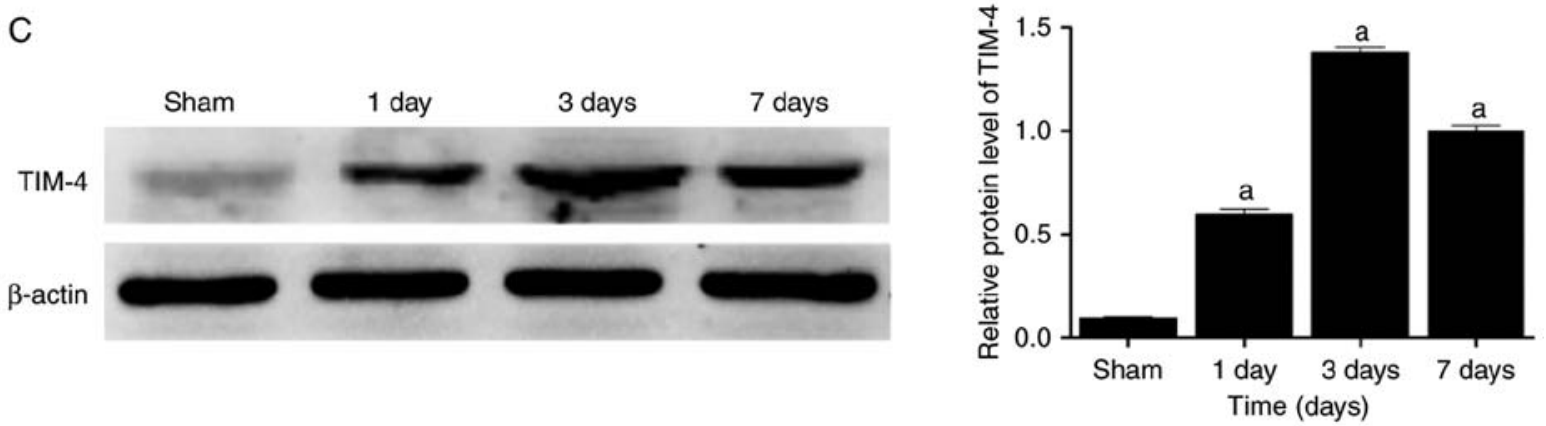

Figure 1. Orthotopic liver transplantation increases KC activation and TIM-4 expression. (A) KCs were isolated from mice in the sham and LT groups 24,48 and $72 \mathrm{~h}$ following surgery. Cells were double stained with PE-CD14 and APC-CD163 and quantified using flow cytometry. (B) Liver samples were obtained from mice in the sham and LT groups and assessed using immunohistochemistry (magnification, x400). Activated hepatic KCs are stained brown. (C) KCs were isolated from mice in the sham and LT groups 1, 3 and 7 days following surgery and TIM-4 expression was analyzed using western blotting. Data are presented as the mean \pm standard deviation. ${ }^{\mathrm{P}}<0.05$ vs. sham group. KC, kupffer cells; TIM-4, T cell immunoglobulin-domain mucin-domain- 4 ; CD, cluster of differentiation; APC, antigen presenting cell; LT, liver transplantation; PE, phycoerythrin; d, days.

method described by Kitamoto et al (21). TUNEL + hepatocyte nuclei were quantified by calculating the mean number of TUNEL + hepatocytes in five random fields of view per animal with 100 nuclei counted per field. The mean percentage of apoptotic cells was calculated.

Statistical analysis. All values are expressed as the mean \pm standard deviation. Data were analyzed using an unpaired two-tailed Student's t-test or one-way analysis of variance with Tukey's post-hoc test. $\mathrm{P}<0.05$ was considered to indicate a statistically significant result. Graft survival was assessed using the Kaplan-Meier method and statistical differences were calculated using the log rank test.

\section{Results}

$A R$ injury following $L T$ increases the frequency of $K C$ activation and TIM-4 expression. KCs are important APCs that serve bimodal roles in the innate and adaptive immune response. It has been demonstrated that liver $\mathrm{KCs}$ engulf and degrade pathogenic microorganisms and remove endotoxins (22). To assess the expression of TIM-4 in KCs following hepatic AR, flow cytometry and immunohistochemistry were performed and the number of activated KCs in transplanted livers were assessed. The number of activated KCs in the
LT group gradually increased with time following surgery compared with the sham group (Fig. 1A and B). KCs were then isolated from mice that had undergone LT and the expression of TIM-4 was measured using western blotting. Mice that had undergone LT exhibited significantly elevated TIM-4 expression 1,3 and 7 days post-surgery $(\mathrm{P}<0.05$ vs. sham group; Fig. 1C). The expression of TIM-4 on day 3 following surgery increased to a peak and remained at a relatively high level, indicating that the expression of TIM- 4 is promoted by activated KCs following LT.

Blockade of TIM-4 in KCs ameliorates AR and reduces the expression of inflammatory cytokines via the nuclear factor $(N F)-\kappa B$ and p38 MAPK signaling pathways. TIM-4 was demonstrated to be present in activated KCs at high levels; therefore, the role of TIM-4 signaling in the function of $\mathrm{KCs}$ was assessed. The fluorescent expression of KCs was markedly higher in the TIM-4 mAb group compared with the sham and control mAb groups (Fig. 2A). The effect of TIM-4 on KCs was determined using flow cytometric analysis. TIM-4 expression in the TIM-4 mAb group was almost entirely blocked compared with the control $\mathrm{mAb}$ group, indicating that the expression of TIM-4 in KCs was successfully disrupted (Fig. 2B).

Compared with the control mAb group, the blockade of KC TIM-4 expression significantly improved hepatic injury, 
A

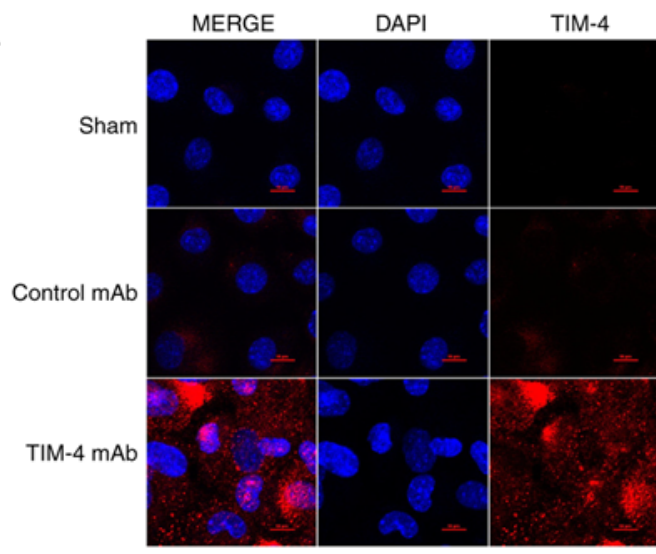

B
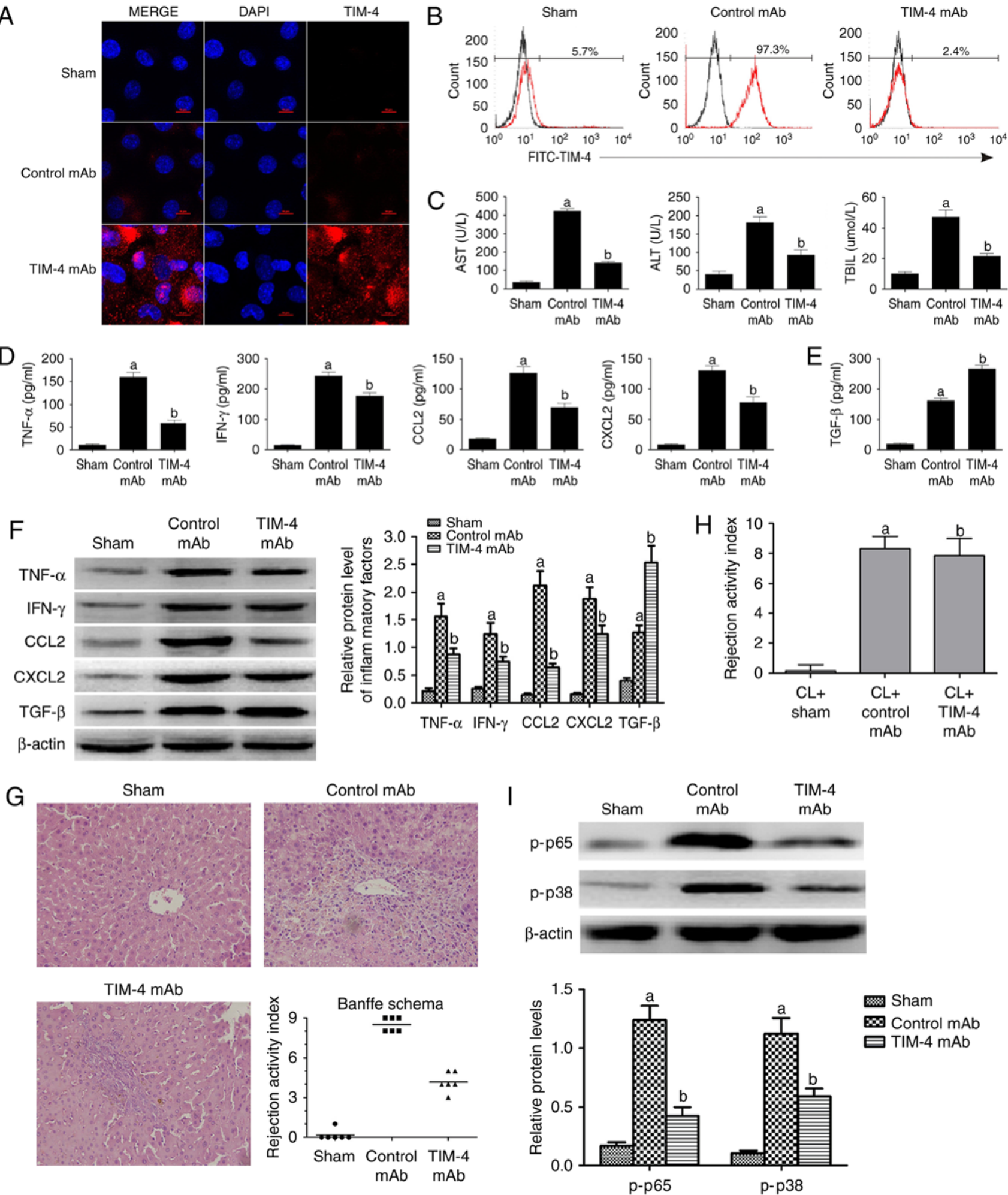

Figure 2. Blockade of TIM-4 improves hepatic acute reaction response injury and reduces the secretion of inflammatory cytokines. (A) KCs were isolated from mice in the sham, control mAb and TIM-4 mAb groups on day 7 post-surgery. Cells were stained with specific secondary antibodies labeled with tetramethylrhodamine (red) and DAPI (blue) and then examined using laser confocal microscopy (magnification x800). (B) KCs were isolated from each group and stained with FITC-TIM-4 mAb for flow cytometry. (C) Blood samples were obtained (0.5 ml/mouse) from murine abdominal aortas in each group on day 7 post-surgery. Levels of AST, ALT and TBIL were determined in a clinical biochemical laboratory. (D-F) Levels of inflammatory cytokines, including TNF- $\alpha$, IFN- $\gamma$, CCL2, CXCL2 and TGF- $\beta$ were detected using ELISA and western blotting. (G) Representative micrographs of the pathological damage observed in each group post-transplantation following staining with hematoxylin and eosin (magnification $\mathrm{x} 400$ ). (H) Donor mice received CL treatment to destroy KCs prior to surgery. orthotopic liver transplantation or sham surgery was subsequently performed and mice were treated either with or without TIM-4 mAb. All mice underwent analysis to determine the RAI score on day 7 following surgery. (I) The expression of key phosphoproteins involved in the NF- $\kappa \mathrm{B}$ and $\mathrm{p} 38$ MAPK signaling pathways, including p65 and p38, respectively, were analyzed using western blotting. Data are presented as the mean \pm standard deviation. ${ }^{\text {aP }}<0.05$ vs. sham group; ${ }^{\mathrm{b}} \mathrm{P}<0.05$ vs. control mAb group. TIM-4, T cell immunoglobulin-domain mucin-domain-4; mAb, monoclonal antibodies; KCs, kupffer cells; FITC, fluorescein isothiocyanate; AST, aspartate aminotransferase; ALT, alanine aminotransferase; TBIL, total bilirubin in serum; TNF- $\alpha$, tumor necrosis factor- $\alpha$; IFN- $\gamma$, interferon- $\gamma$; CCL2, chemokine ligand ; CXCL2, C-X-C motif chemokine ligand 2 ; TGF- $\beta$, transforming growth factor- $\beta$; CL, clondronate liposomes; NF- $\mathrm{B}$, nuclear factor- $\kappa \mathrm{B} ; \mathrm{MAPK}$, mitogen-activated protein kinase. 
as determined by the liver function indices of AST, ALT and TBIL (each P<0.05; Fig. 2C). Furthermore, it was revealed that TIM-4 disruption significantly reduced levels of the inflammatory cytokines TNF- $\alpha$, IFN- $\gamma$, CCL2 and CXCL2 (each $\mathrm{P}<0.05$ vs. control mAb group; Fig. $2 \mathrm{D}$ and $\mathrm{F}$ ) and significantly enhanced the levels of TGF- $\beta(\mathrm{P}<0.05$ vs. control mAb group; Fig. 2E) in the liver, thus reversing the effects of AR. Additionally, visible focal necrosis and vacuolization of liver parenchyma with lymphocyte infiltration was observed in the control $\mathrm{mAb}$ group and classified as severe AR according to the Banffe schema (20). However, tissues from mice in the TIM-4 mAb group exhibited reduced infiltration of lymphocytes surrounding the portal area. AR severity was determined following a previously described protocol (20) and the rejection activity index (RAI) was identified as being significantly lower than that of the control $\mathrm{mAb}$ group $(\mathrm{P}<0.05$; RAI score: $4.2 \pm 0.7$ vs. $8.5 \pm 0.5$; Fig. $2 \mathrm{G}$ ). These results suggest that the blockade of TIM- 4 by mAb contributes to AR amelioration and inflammatory cytokine downregulation.

CL stimulates the depletion of macrophages in the liver (23). To determine the function of KCs in vivo, the livers of donor mice were treated with CL to destroy hepatic KCs. The RAI score of liver grafts treated with CL+TIM- $4 \mathrm{mAb}$ was associated with severe AR and there were no significant differences in RAI scores between the CL+TIM- 4 mAb and $\mathrm{CL}+$ control mAb groups (Fig. $2 \mathrm{H}$ ), suggesting that the disruption of TIM-4 expressed on KCs is critical to the improvement of AR, rather than the TIM-4 that is expressed on other hepatic APCs.

To analyze the possible pathways involved in this process, the expression of key phosphorylated proteins involved in the NF- $\mathrm{KB}$ and $\mathrm{p} 38$ MAPK signaling pathways, including p65 and p38 were assessed. A significant decrease in the expression of p-p65 and p-p38 was observed in mice following treatment with TIM-4 mAb ( $\mathrm{P}<0.05$ vs. control mAb group; Fig. $2 \mathrm{I})$. Therefore, the blockade of KC TIM-4 may inhibit NF- $\mathrm{KB}$ and p38 MAPK signaling to improve liver transplant injury.

Blockade of TIM-4 expressed by KCs with exogenous TGF- $\beta$ inhibits Th2 differentiation and promotes iTreg generation in vitro. As aforementioned, it was determined that the blockade of TIM- 4 expressed by KCs enhances the secretion of TGF- $\beta$, which is a protein that inhibits the polarization and facilitates the proliferation of $\mathrm{Th} 1 / \mathrm{Th} 2$ and Tregs, respectively. Therefore, the effect of TIM- 4 blockade $(0.5 \mu \mathrm{g} / \mathrm{ml})$ with exogenous TGF- $\beta(1 \mathrm{ng} / \mathrm{ml})$ on the differentiation of naive $\mathrm{CD} 4^{+}$ $\mathrm{T}$ cells was assessed in vitro. TIM- $4^{+} \mathrm{KCs}$ were isolated from model mice and purified using FACS. There was no significant difference in the $\mathrm{KC}$ antigen-presenting ability between the control mAb and TIM- $4 \mathrm{mAb}$ groups. However, compared with the TIM- $4 \mathrm{mAb}$ group, the TGF- $\beta+$ TIM- $4 \mathrm{mAb}$ group exhibited a significant decrease in $\mathrm{KC}$ antigen-presenting ability ( $\mathrm{P}<0.05$; Fig. $3 \mathrm{~A})$. These results indicate that the TIM-4 blockade does not decrease the antigen-presenting capacity of $\mathrm{KCs}$, however additional TGF- $\beta$ treatment does. TIM $-4^{+} \mathrm{KCs}$ were subsequently incubated with naive $\mathrm{CD} 4^{+} \mathrm{CD} 25^{-} \mathrm{T}$ cells. It was revealed that the blockade of TIM- 4 with added TGF- $\beta$ caused a significantly greater reduction in $\mathrm{CD} 4^{+} \mathrm{CD} 25^{-} \mathrm{T}$ cell proliferation compared with TGF- $\beta$ and TIM- 4 treatment alone $(\mathrm{P}<0.05$; Fig. 3B). Furthermore, the measurement of supernatants co-cultured cohorts demonstrated that TGF- $\beta$ treatment or TIM-4 blockade significantly decreased levels of the cytokines IL-4, IL- 6 and IL-13 (each $\mathrm{P}<0.05$ vs. control $\mathrm{mAb}$; Fig. $3 \mathrm{C}$ ). The combination of TGF- $\beta$ and TIM- 4 treatment further enhanced this effect $(\mathrm{P}<0.05$; Fig. $3 \mathrm{C})$, indicating that $\mathrm{Th} 2$ polarization was effectively inhibited. The proportion of Treg $\left(\mathrm{CD} 4^{+} \mathrm{CD} 25^{+} \mathrm{Foxp}^{+}\right)$cells was significantly increased in the TGF- $\beta$ and TIM- 4 mAb groups compared with the control $\mathrm{mAb}$ group $(\mathrm{P}<0.05$; Fig. $3 \mathrm{D})$ and the proportion of Treg cells was significantly enhanced in the combined TGF- $\beta+$ TIM- 4 mAb group $(\mathrm{P}<0.05$; Fig. $3 \mathrm{D})$. These results suggest that the TIM-4 blockade serves a crucial role in directing the conversion of iTreg and that the addition of TGF- $\beta$ treatment induces an even greater effect.

Blocking TIM-4 promotes iTreg expansion by inhibiting the IL-4/STAT6/Gata3 signaling pathway. The TIM-4 blockade of KCs reduced the expression of IL-4 and triggered the conversion of iTregs. The addition of exogenous low-dose TGF- $\beta$ amplified this effect. It has been demonstrated that STAT6 signaling inhibits iTreg by binding to the Foxp3 promoter, which directly interferes with the transcription of Foxp3 (24). To determine the role of the IL-4/STAT6/Gata3 pathway in the generation of iTregs, fluorescent cell sorting was performed to attain TIM- $4^{+}$and TIM- $4^{-} \mathrm{KCs}$ in the LT group. These were then co-cultured with naive $\mathrm{CD} 4^{+} \mathrm{T}$ cells and the expression of p-STAT6 in T cells was assessed. The results demonstrated that levels of p-STAT6 in $\mathrm{CD} 4^{+} \mathrm{T}$ cells co-cultured with TIM- $4^{+} \mathrm{KCs}$ were significantly higher than those in $\mathrm{CD} 4^{+} \mathrm{T}$ cells co-cultured with TIM- $4^{-} \mathrm{KCs}(\mathrm{P}<0.05$; Fig. 4A). TIM- $4^{+} /$TIM$^{-} 4^{-} \mathrm{KCs}$ were then co-cultured with naive $\mathrm{CD} 4^{+} \mathrm{T}$ cells (which received either no pretreatment or pretreatment with TIM-4 mAb) to detect levels of p-STAT6. It was demonstrated that the addition of TIM- $4 \mathrm{mAb}$ significantly blocked the expression of p-STAT6 in CD4 ${ }^{+}$ T cells co-cultured with TIM- $4^{+} \mathrm{KCs}(\mathrm{P}<0.05)$, but did not affect p-STAT6 expression in $\mathrm{CD} 4^{+} \mathrm{T}$ cells co-cultured with TIM-4- KCs (Fig. 4B). The exogenous addition of IL-4 to TIM- $4^{+} \mathrm{KCs}$ co-cultured with naive $\mathrm{CD} 4^{+} \mathrm{T}$ cells demonstrated that the inhibition of p-STAT6 expression induced by TIM- $4 \mathrm{mAb}$ was significantly reversed by IL-4 $(\mathrm{P}<0.05$; Fig. 4C). Furthermore, the blockade of TIM-4 with additional TGF- $\beta$ in the co-cultured model significantly promoted the expression of Foxp3 $(\mathrm{P}<0.05)$ and had a greater suppressive effect on Gata3 compared with TIM-4 blockade alone $(\mathrm{P}<0.05$; Fig. 4D). Collectively, these data reveal that the generation of the iTreg phenotype by TIM-4 blockade is dependent on the inhibition of the IL-4/STAT6/Gata3 signaling pathway.

TIM-4 mAb combined with TGF- $\beta$ produces a lower AR and extends the survival time of mice following $L T$. The effect of TIM-4 blockade in combination with TGF- $\beta$ on AR was assessed in vivo. Recipient mice were injected with either anti-TIM-4 mAb (0.35 mg/mouse), $0.5 \mathrm{ml} \mathrm{TGF-} \beta$ ( $1 \mathrm{ng} / \mathrm{ml})$ or the two in combination via murine portal veins to establish a model of LT. Treatment was administered continuously at the same dose for a total of 2 days following surgery. The results of hepatic function and apoptotic tests indicated that TIM- 4 mAb combined with TGF- $\beta$ induced a more significant 

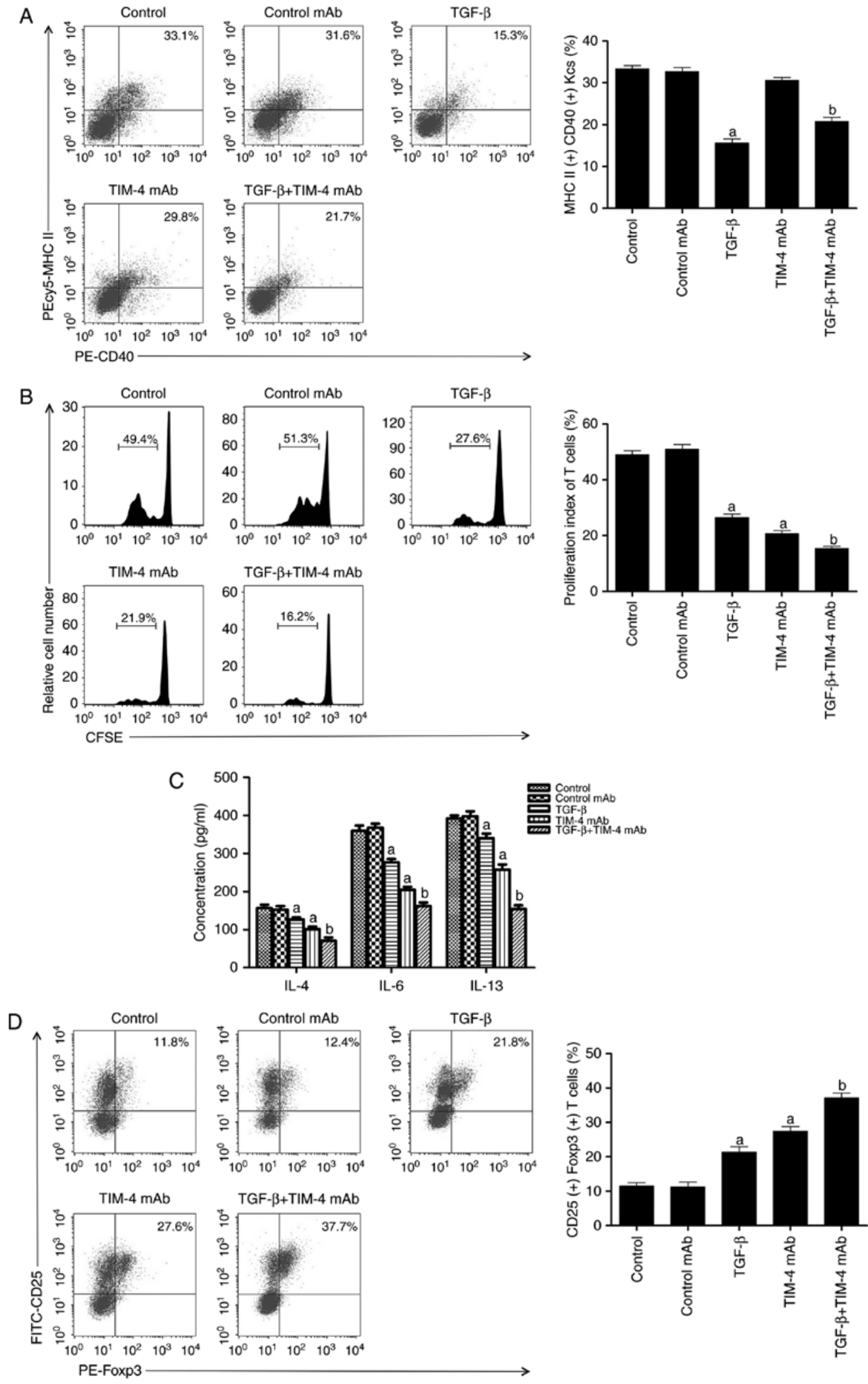

Figure 3. The effect of TIM-4 blockade with addition of exogenous TGF- $\beta$ on inhibiting T helper 2 cell differentiation and inducing the conversion of $\mathrm{CD}^{+} \mathrm{CD} 25^{+} \mathrm{Foxp}^{+} \mathrm{T}$ regulatory cells. (A) TIM $-4^{+} \mathrm{KCs}$ were isolated from model mice and purified using fluorescence activated cell sorting, followed by addition of control mAb/TGF- $\beta /$ TIM- $4 \mathrm{mAb} / \mathrm{TGF}-\beta+\mathrm{TIM}-4 \mathrm{mAb}$ into medium for incubation. Following washing and resuspension of cells, they were stained with PEcy5-MHC II and PE-CD40 antibodies and acquired for FACS analysis. (B) Spleen CD4 ${ }^{+} \mathrm{CD} 25^{-} \mathrm{T}$ cells were purified from recipient mice and labeled with CFSE, followed by co-culturing with KCs in condition described in A (control as untreated). The proliferation of $\mathrm{T}$ cells was then determined using a CFSE dilution gated on CD4 $4^{+}$populations. (C) The supernatants of the co-cultured system, including the cytokines IL-4, IL- 6 and IL-13, were detected using enzyme-linked immunosorbent assay. (D) Splenic CD4 $4^{+} \mathrm{CD} 25^{-} \mathrm{T}$ cells were purified from recipient mice and co-cultured with $\mathrm{KCs}$ in conditions as described in A. Following washing and re-suspension, the cells were stained with PE-Foxp3 and FITC-CD25 antibodies and underwent FACS analysis. Data are presented as the mean \pm standard deviation. ${ }^{a} \mathrm{P}<0.05$ vs. control and control mAb groups; ${ }^{\mathrm{b}} \mathrm{P}<0.05$ vs. TGF- $\beta$ and TIM- $4 \mathrm{mAb}$ groups. TIM- 4 , T cell immunoglobulin-domain mucin-domain-4; TGF- $\beta$, transforming growth factor- $\beta$; KCs, kupffer cells; mAb, monoclonal antibodies; MHC II, major histocompatibility complex II; CD, cluster of differentiation; FACS, fluorescence-activated cell sorting; CFSE, carboxyfluorescein succinimidyl ester; IL, interleukin; Foxp3, forkhead box P3; FITC, fluorescein isothiocyanate; PE, phycoerythrin; PEcy5, phycoerythrin-streptavidin. 
A
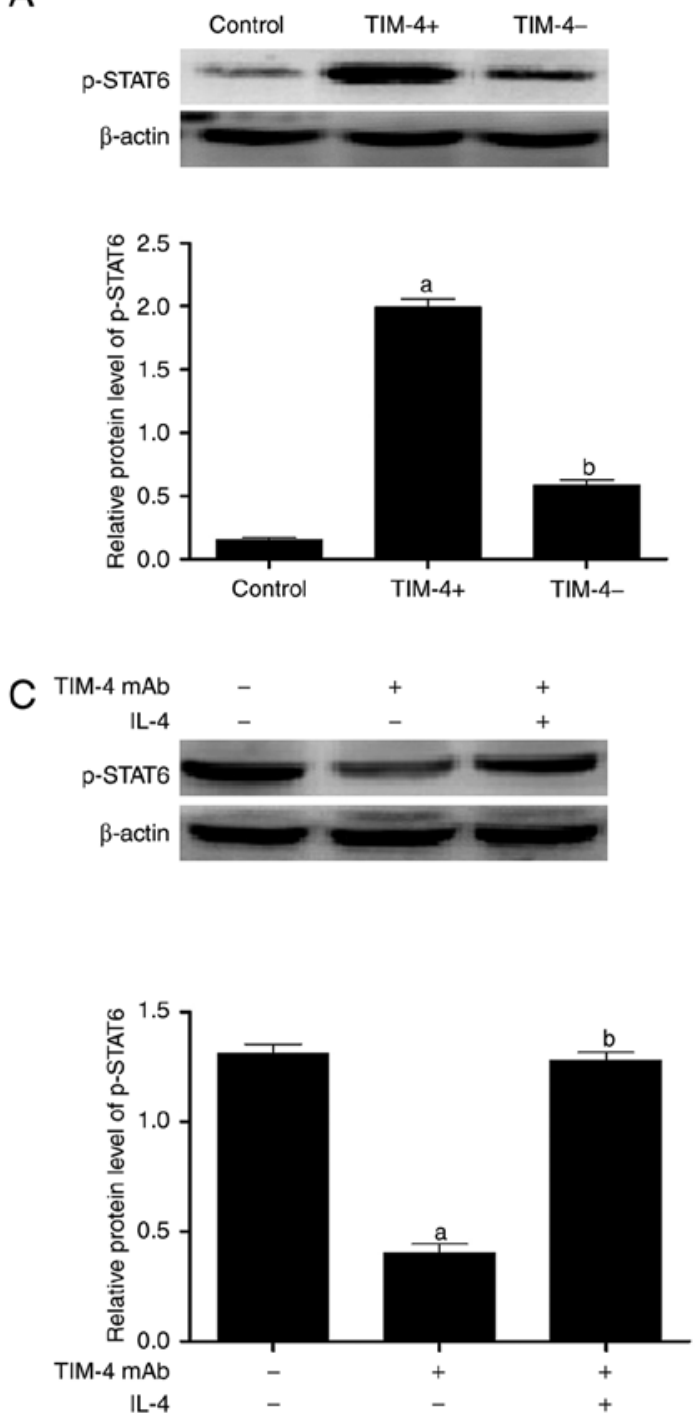

B
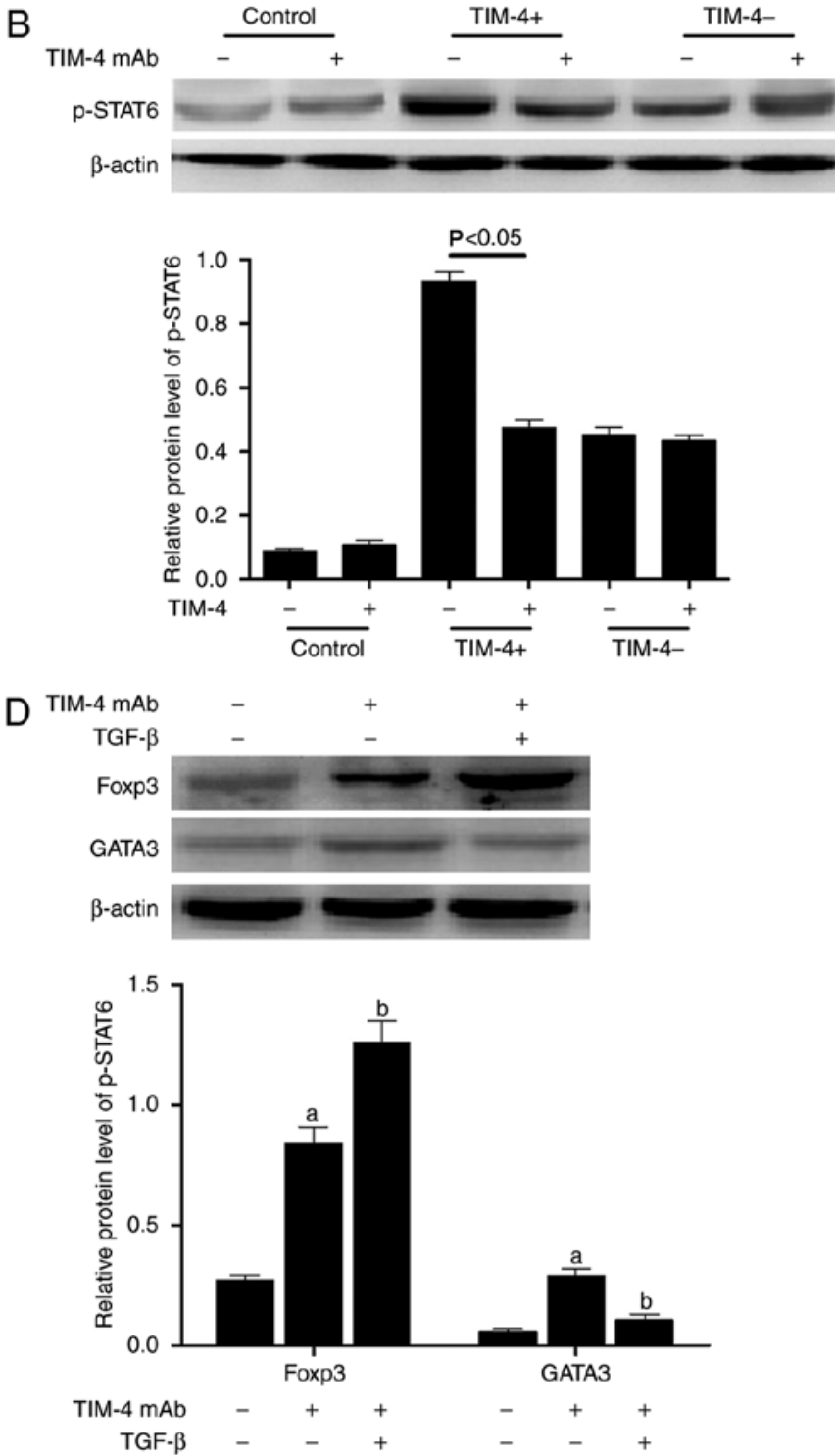

Figure 4. TIM-4 blockade stimulates the differentiation of $\mathrm{T}$ cells into $\mathrm{CD} 4^{+} \mathrm{CD} 25^{+} \mathrm{Foxp} 3^{+} \mathrm{T}$ regulatory cells via the IL-4/STAT6/Gata3 pathway. (A) TIM- ${ }^{+}$ and TIM-4 KCs were obtained from mice following liver transplantation and co-cultured with naive $\mathrm{CD}^{+}{ }^{+} \mathrm{T}$ cells. The expression of p-STAT6 in T cells was determined using western blotting. (B) TIM-4 mAb was added to co-cultured cohorts as described in A, to analyze the expression of p-STAT6 in T cells. (C) The exogenous addition of IL-4 to TIM- $4^{+} \mathrm{KCs}$ co-cultured with naive $\mathrm{CD} 4^{+} \mathrm{T}$ cells (that received either no pretreatment or pretreatment with TIM- $4 \mathrm{mAb}$ ) was performed and the expression of p-STAT6 in T cells was analyzed. (D) TGF- $\beta$ was added to TIM- $4^{+}$KCs co-cultured with naive CD4 ${ }^{+}$T cells (that received either no pretreatment or pretreatment with TIM-4 mAb) to determine the expression of Foxp3 and Gata3 protein in T cells. Data are presented as the mean \pm standard deviation of the mean. ${ }^{\mathrm{P}} \mathrm{P}<0.05$ vs. control; ${ }^{\mathrm{b}} \mathrm{P}<0.05$ vs. TIM- $4^{+}$group. TIM- 4 , T cell immunoglobulin-domain mucin-domain- 4 ; IL- 4 , interleukin-4; p-, phosphorylated; STAT6, signal transducer and activator of transcription 6; Gata3, transcription factor gata3; CD, cluster of differentiation; mAb, monoclonal antibodies; KCs, kupffer cells; TGF- $\beta$, transforming growth factor- $\beta$; Foxp3, forkhead box P3.

improvement of liver injury compared with the TGF- $\beta$ or TIM-4 mAb groups $(\mathrm{P}<0.05$; Fig. 5A) and evidently significantly ameliorates hepatocyte apoptosis in LT models on day 7 following surgery (P<0.05; Fig. 5B). As the present study demonstrated, TIM- 4 mAb combined with TGF- $\beta$ induced the generation of significantly more $\mathrm{CD} 4^{+} \mathrm{CD} 25^{+} \mathrm{Foxp} 3^{+}$ $\mathrm{T}$ cells than in mice treated with TGF- $\beta$ or TIM- $4 \mathrm{mAb}$ alone $(\mathrm{P}<0.05 ;$ Fig. 5C). The mean survival time of mice treated with TGF- $\beta$ and TIM- 4 mAb was markedly extended ( $>100$ days) and was significantly longer than those that received TGF- $\beta$ or TIM- $4 \mathrm{mAb}$ alone $(\mathrm{P}<0.05$; Fig. 5D). These results indicate that TIM- 4 blockade combined with additional TGF- $\beta$ may ameliorate AR more effectively and potentially induce the formation of immunosuppressive cells.

\section{Discussion}

The results of previous studies have demonstrated that TIM-4 is expressed on mature APCs and engages TIM-1 ligands to co-stimulate the activation of $\mathrm{T}$ cells in the adaptive immune response $(9,10,25)$. It has been demonstrated that the interaction between TIM- 4 and TIM-1 expressed on activated CD4 ${ }^{+}$ $\mathrm{T}$ cells increases the proliferation of $\mathrm{T}$ cells and the polarization of Th2 (26). However, a previous study demonstrated that TIM-4-Ig fusion proteins inhibit naive $\mathrm{CD}^{+} \mathrm{T}$ cell activation via a receptor other than TIM-1 in vitro (11). KCs are the largest type of APC and function to mediate the balance between the effector and regulatory $\mathrm{T}$ cell responses. KCs are activated following LT via various pathways. Activated 
A

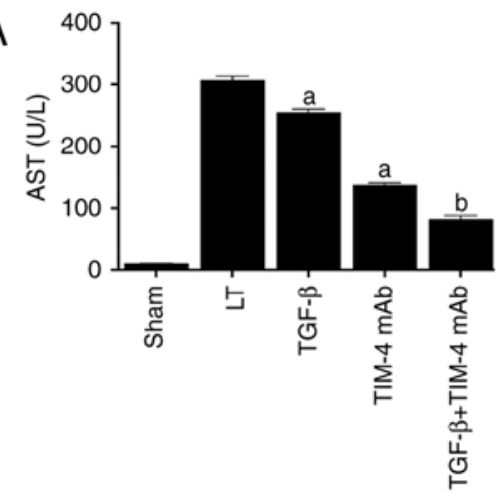

B
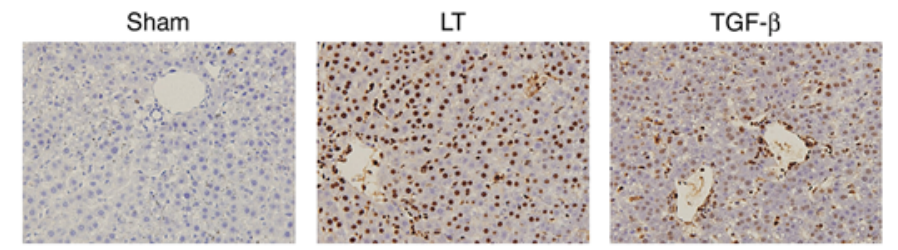

TIM-4 mAb

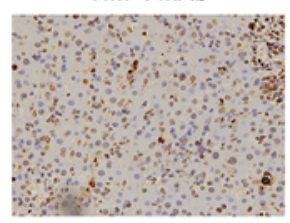

TGF- $\beta+$ TIM- 4 mAb

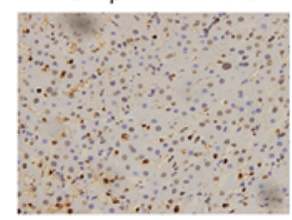

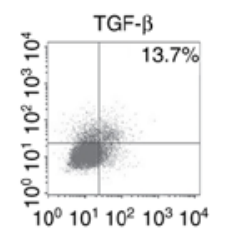
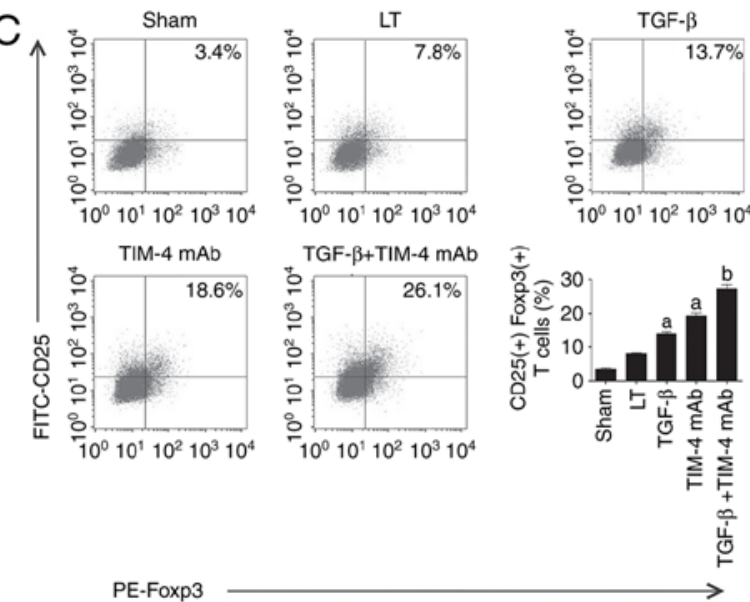
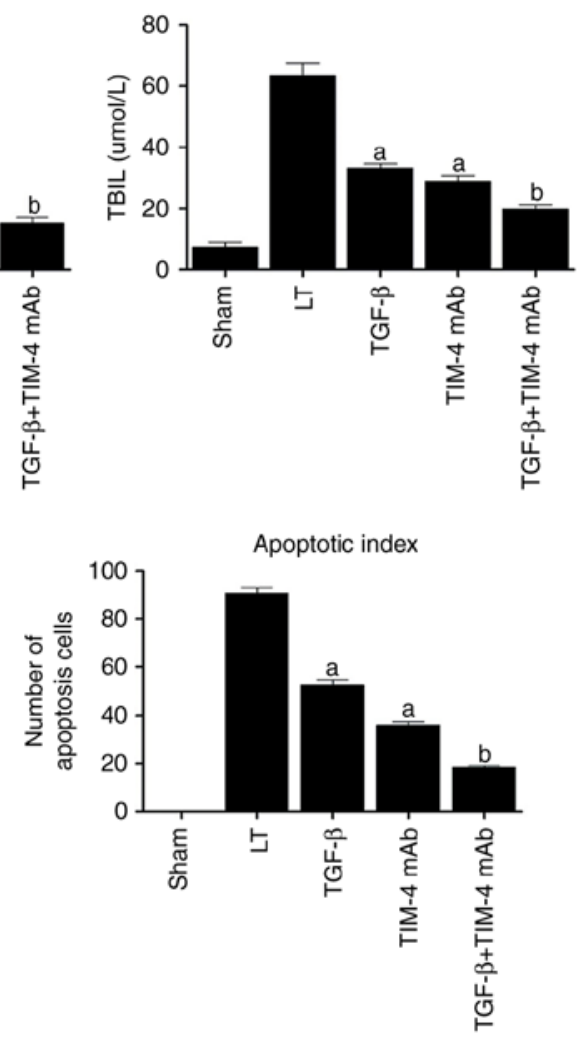

PE-Foxp3
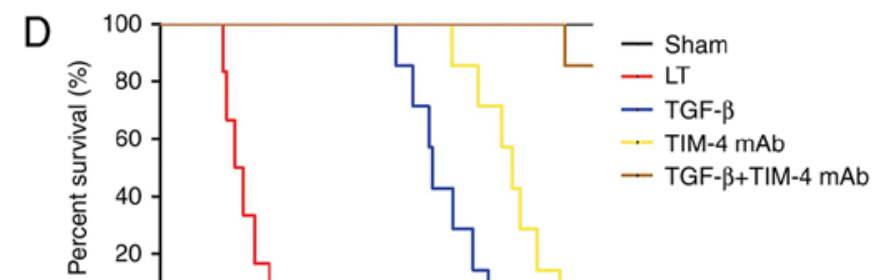

Figure 5. The effect of TIM-4 blockade with exogenous TGF- $\beta$ injection on acute reaction response in vivo. (A) Mice were injected with either anti-TIM-4 mAb $(0.35 \mathrm{mg} / \mathrm{mouse}), 0.5 \mathrm{ml} \mathrm{TGF}-\beta(1 \mathrm{ng} / \mathrm{ml})$ or in combination via murine portal veins to establish LT (LT group were treated with PBS as control). Treatment in each group was administered continuously at the same dose for a total of 2 days following surgery. Levels of AST, ALT and TBIL were determined in a clinical biochemical laboratory on day 7 following surgery. (B) Hepatocyte apoptosis was detected using the terminal deoxynucleotidyl transferase-mediated 2'-deoxyuridine 5'-triphosphate nick-end labeling method (magnification x400). (C) T cells were purified from hepatic tissue. Following washing and re-suspension, cells were stained with PE-Foxp3 and FITC-CD25 antibodies and acquired for fluorescence-activated cell sorting analysis. (D) Mice survival time was observed and analyzed using the Log-rank test. Data are presented as the mean \pm standard deviation of the mean. ${ }^{\text {ap }}<0.05$ vs. LT group; ${ }^{b} \mathrm{P}<0.05$ vs. TGF- $\beta$ and TIM-4 mAb groups. TIM-4, T cell immunoglobulin-domain mucin-domain- 4 ; TGF- $\beta$, transforming growth factor- $\beta$; mAb, monoclonal antibodies; LT, liver transplantation; AST, aspartate aminotransferase; ALT, alanine aminotransferase; TBIL, total bilirubin in serum; Foxp3, forkhead box P3; FITC, fluorescein isothiocyanate; $\mathrm{CD}$, cluster of differentiation; $\mathrm{PE}$, phycoerythrin.

KCs possess a strong antigen presenting capacity, demonstrated by their high expression of major histocompatibility complex II and co-stimulatory molecules (27). Furthermore, activated KCs generate large quantities of Th1 cytokines, which activate antigen-specific T cells to induce AR (13). However, activated KCs also upregulate the expression of Fas ligand, which binds to $\mathrm{Fas}^{+} \mathrm{T}$ cells to induce apoptosis and promote the secretion of $\mathrm{Th} 2$ cytokines, thereby inhibiting the immune response (28). Therefore, the effect of TIM-4 on
KCs may serve a critical role in the immunological balance associated with LT.

TIM-4 mediates co-stimulatory signaling and induces the phagocytosis of apoptotic cells (29). It has been determined that TIM-4 expression increases in a dose-dependent manner in $\mathrm{CD}_{11} \mathrm{~b}^{+}$monocyte macrophages treated with lipopolysaccharide $(9,30)$. By establishing a model of OLT, the present study demonstrated that TIM-4 expression increases and is maintained at high levels following the activation of pathological 
inflammation-induced KCs. It has been demonstrated that the TIM-4 blockade inhibits the production of pro-inflammatory cytokines but does not affect the phagocytosis of apoptotic bodies mediated by DCs (15). Furthermore, it has been demonstrated that the disruption of TIM-4 signaling inhibits macrophage and neutrophil migration/function, diminishes the phagocytosis of necrotic hepatocytes and suppresses the activation of TLR2/4/9-dependent signaling (14). The present study disrupted KC-expressed TIM-4 using anti-TIM-4 mAb and indicated that the TIM- 4 blockade contributed to the amelioration of hepatic injury and reduced the release of inflammatory cytokines, including TNF- $\alpha$, IFN- $\gamma$, CCL2 and CXCL2. The degree of AR in the tissue sections of mice that received TIM- 4 mAb was markedly improved and was exhibited only a mild rejection response. These results indicated that TIM-4 serves an important role in LT injury and inflammation.

Proteins in the NF- $\mathrm{BB}$ family act as transcription factors and serve key roles during the regulation of inflammation (31). TLR activation promotes the activation of innate immune responses via the myeloid differentiation primary response 88- or toll-interleukin receptor-domain-containing adaptor-inducing IFN- $\beta$-dependent pathways, which are instrumental for downstream $\mathrm{NF}-\kappa \mathrm{B}$ activation and subsequent inflammatory reactions $(14,32)$. In addition, it has been demonstrated that the activation of KCs is closely associated with p38 MAPK signaling in endoplasmic reticulum stress and ischemia reperfusion injury (32). TIM-4 fragment crystallizable has been reported to inhibit the proliferation and the differentiation of $\mathrm{T}$ cells, primarily via the inhibition of MAPK signaling (12). The activation of NF- $\kappa \mathrm{B}$ and MAPK are considered to be important for the production of inflammatory cytokines in $\mathrm{KCs}(32,33)$. The present study demonstrated that the blockade of KC TIM-4 reduces the phosphorylation of p65 and p38, which are key proteins of the NF- $\mathrm{KB}$ and p38 MAPK signaling pathways. The results therefore demonstrated that TIM-4 disruption in KCs may inhibit the NF- $\kappa \mathrm{B}$ and p38 MAPK signaling pathways to ameliorate AR damage in transplanted livers.

The present study also identified that TGF- $\beta$ levels were significantly increased in mice treated with TIM-4 mAb. TGF- $\beta$ is a key mediator of immune regulation and tolerance and serves a functional role in the induction and inhibition of Foxp3 and T-bet/Gata3 expression, respectively. However, the expression of TGF- $\beta$ is usually decreased following LT (34). The TGF- $\beta$-mediated transcription of Foxp3 is associated with the Smad pathway $(35,36)$. Distal to the Foxp3 gene is a conservative enhancer, which associates with Smad3 and the nuclear factor of activated $\mathrm{T}$ cells to synergistically induce the transcription of Foxp3 (36). In addition, TIM-4 signaling promotes Th2 differentiation, the response to which markedly inhibits the induction of peripheral Tregs from naive $\mathrm{CD}^{+} \mathrm{T}$ cells. The present study therefore utilized a highly specific anti-TIM- 4 mAb without exogenous TGF- $\beta$ and the results indicated that the antigen presenting capacity of $\mathrm{KCs}$ that expressed TIM-4 following blocking was not weakened; however, the reverse occurred following TIM-4 blockade combined with TGF- $\beta$ treatment in vitro. The results indicated that the addition of exogenous TGF- $\beta$ favored negative immune regulation in $\mathrm{KCs}$, which is conducive to the effects of immunosuppression. Furthermore, the proliferation of $\mathrm{CD}^{+}$ $\mathrm{T}$ cells in a co-culture system and Th2 cytokines, including IL-4, IL-6 and IL-13 were significantly suppressed in the presence of combined TIM- 4 mAb and TGF- $\beta$, compared with individual treatments administered alone. IL-4 suppresses the upregulation of Foxp3 in $\mathrm{CD}^{+}{ }^{+} \mathrm{T}$ cells and the suppression of Th2 differentiation is the central mechanism of Treg induction $(15,37,38)$. IL-4 may also block the generation of TGF- $\beta$-mediated Treg differentiation and induce the population of Th cells $(15,24)$. The present study confirmed that TIM-4 blockade with the addition of exogenous TGF- $\beta$ exhibited a greater effect on the induction of $\mathrm{CD} 4^{+} \mathrm{CD} 25^{+} \mathrm{Foxp} 3^{+} \mathrm{T}$ cells. It was further demonstrated that the TIM-4 blockade in TIM- $4^{+}$ KCs attributes to iTreg conversion via IL-4/STAT6/Gata3 signaling as the transcription of these proteins interfere with the transcription of Foxp3. The differentiation of $\mathrm{CD}^{+} \mathrm{T}$ cells is determined by the relative quantities of STAT6/Gata3 and Foxp3.

A previous study demonstrated that the administration of TGF- $\beta$ in the presence of IL- 6 promotes the generation of pro-inflammatory Th17, causing chronic allograft rejection (39). In addition, the direct blockade of IL-4 also promotes the development of Th2-driven diseases (40) and reduces the long-term allograft survival of transplant models with a STAT6 deficiency (41). However, the isolated impairment of Th2 differentiation is not sufficient to promote immune tolerance. Based on these results, the present study assessed the effect of TIM-4 blockade with the addition of exogenous TGF- $\beta$ on AR in vivo. The results demonstrated that the combined treatment of anti-TIM- 4 mAb and TGF- $\beta$ was more effective at protecting mice from AR injury that when either reagent was used alone. It was also revealed that combined treatment induced the generation of iTregs in liver allografts. The survival time of mice treated with anti-TIM-4 mAb and TGF- $\beta$ was significantly longer than those in other treatment groups. TGF- $\beta$ is a primary pro-fibrogenic medium derived from KCs and hepatocytes in inflammation. However, TGF- $\beta$-induced hepatic fibrosis resulting from chronic hepatopathy with various etiologies, including HBV infection and allograft rejection, is a long-term and reversible process (42). The present study utilized exogenous TGF- $\beta(0.5 \mathrm{ml} / \mathrm{mouse}$, $1 \mathrm{ng} / \mathrm{ml}$ ) injections for 2 days following surgery to establish LT models. No marked changes in hepatofibrosis pathophysiology were observed in any group. Consequently, the blockade of KC-expressed TIM-4, in combination with an exogenous TGF- $\beta$ injection, exhibited synergistic effects on the improvement of AR of LT.

In conclusion, the present study demonstrated that LT may lead to the augmented expression of KC TIM-4 and that TIM-4 blockade markedly improves in vivo AR injury by inhibiting $\mathrm{NF}-\kappa \mathrm{B}$ and p38 MAPK signaling. Additionally, TIM- 4 blockade increased TGF- $\beta$ levels, inhibited Th2 differentiation and promoted iTreg conversion by suppressing IL-4/STAT6/Gata3 signaling. These effects were demonstrated more pronounced following the addition of exogenous TGF- $\beta$. Therefore, the results of the present study indicate that KC-expressed TIM-4 blockade in combination with an exogenous TGF- $\beta$ injection may be a useful strategy to treat AR and improve the survival rates of mice that receive liver allografts. However, further studies that utilize other animal 
models of liver allografts are required to determine whether this may be the case in humans too.

\section{Acknowledgements}

Not applicable.

\section{Funding}

The present study was supported by the National Natural Science Foundation of China (grant nos. 81370580, 81670599 and 81671580 ) and by the National Science Fund for Distinguished Young Scholars (grant no. 81600504).

\section{Availability of data and materials}

The analyzed data sets generated during the study are available from the corresponding author on reasonable request.

\section{Authors' contributions}

ML and JG conceived and designed the study, HW and XX performed the experiments, JL analyzed the data and HW drafted the manuscript. All authors read and approved the final manuscript.

\section{Ethics approval and consent to participate}

All experiments were approved by the Animal Care and Use Committee of Second Affiliated Hospital of Chongqing Medical University (Chongqing, China).

\section{Consent for publication}

Not applicable.

\section{Competing interests}

The authors declare that they have no competing interests.

\section{References}

1. Knechtle SJ and Kwun J: Unique aspects of rejection and tolerance in liver transplantation. Semin Liver Dis 29: 91-101, 2009.

2. Yoshida O, Dou L, Kimura S, Yokota S, Isse K, Robson SC, Geller DA and Thomson AW: CD39 deficiency in murine liver allografts promotes inflammatory injury and immune-mediated rejection. Transpl Immunol 32: 76-83, 2015.

3. Shen ZY, Wu B, Liu T, Yang Y, Yin ML, Zheng WP, Zhang BY and Song HL: Immunomodulatory effects of bone marrow mesenchymal stem cells overexpressing heme oxygenase-1: Protective effects on acute rejection following reduced-size liver transplantation in a rat model. Cell Immunol 313: 10-24, 2017.

4. Meyers JH, Sabatos CA, Chakravarti S and Kuchroo VK: The TIM gene family regulates innate and adaptive immunity. Trends Mol Med 11: 362-269, 2005.

5. Freeman GJ, Casasnovas JM, Umetsu DT and DeKruyff RH: TIM genes: A family of cell surface phosphatidylserine receptors that regulate innate and adaptive immunity. Immunol Rev 235 $172-189,2010$

6. Li Z, Ju Z and Frieri M: The T-cell immunoglobulin and mucin domain (Tim) gene family in asthma, allergy, and autoimmunity. Allergy Asthma Proc 34: e21-e26, 2013.

7. Yeung MY, McGrath M and Najafian N: The emerging role of the TIM molecules in transplantation. Am J Transplant 11: 2012-2119, 2011
8. Baghdadi M, Yoneda A, Yamashina T, Nagao H, Komohara Y, Nagai S, Akiba H, Foretz M, Yoshiyama H, Kinoshita I, et al: TIM-4 glycoprotein-mediated degradation of dying tumor cells by autophagy leads to reduced antigen presentation and increased immune tolerance. Immunity 39: 1070-1081, 2013.

9. Rodriguez-Manzanet R, Meyers JH, Balasubramanian S, Slavik J, Kassam N, Dardalhon V, Greenfield EA, Anderson AC, Sobel RA, Hafler DA, et al: TIM-4 expressed on APCsinduces T cell expansion and survival. J Immunol 180: 4706-4713, 2008.

10. Meyers JH, Chakravarti S, Schlesinger D, Illes Z, Waldner H, Umetsu SE, Kenny J, Zheng XX, Umetsu DT, DeKruyff RH, et al: TIM- 4 is the ligand for TIM-1 and the TIM-1-TIM-4 interaction regulates T cell proliferation. Nat Immunol 6: 455-464, 2005.

11. Mizui M, Shikina T, Arase H, Suzuki K, Yasui T, Rennert PD, Kumanogoh A and Kikutani $\mathrm{H}$ : Bimodal regulation of T cell-mediated immune responses by TIM-4. Int Immunol 20: 695-708, 2008

12. Cao W, Ryan M, Buckley D, O'Connor R and Clarkson MR: Tim- 4 inhibition of T-cell activation and $\mathrm{T}$ helper type 17 differentiation requires both the immunoglobulin $\mathrm{V}$ and mucin domains and occurs via the mitogen-activated protein kinase pathway. Immunology 133: 179-189, 2011.

13. Chen Y, Liu Z, Liang S, Luan X, Long F, Chen J, Peng Y, Yan L and Gong J: Role of Kupffer cells in the induction of tolerance of orthotopic liver transplantation in rats. Liver Transpl 14: 823-836, 2008.

14. Ji H, Liu Y, Zhang Y, Shen XD, Gao F, Busuttil RW, Kuchroo VK and Kupiec-Weglinski JW: T-Cell immunoglobulin and mucin domain 4 (TIM-4) signaling in innate immune-mediated liver ischemia-reperfusion injury. Hepatology 60: 2052-2064, 2014.

15. Yeung MY, McGrath MM, Nakayama M, Shimizu T, Boenisch O, Magee CN, Abdoli R, Akiba H, Ueno T, Turka LA and Najafian N: Interruption of dendritic cell-mediated TIM-4 signaling induces regulatory $\mathrm{T}$ cells and promotes skin allograft survival. J Immunol 191: 4447-4455, 2013.

16. National Research Council (US) Committee for the Update of the Guide for the Care and Use of Laboratory Animals. Guide for the Care and Use of Laboratory Animals. 8th edition. National Academies Press (US), Wasington, DC, 2011.

17. Peng Y, Gong JP, Yan LN, Li SB and Li XH: Improved two-cuff technique for orthotopic liver transplantation in rat. Hepatobiliary Pancreat Dis Int 3: 33-37, 2004.

18. Li PZ, Li JZ, Li M, Gong JP and He K: An efficient method to isolate and culture mouse Kupffer cells. Immunol Lett 158: 52-56, 2014.

19. Schmittgen TD: Real-time quantitative PCR. Methods 25: 383-385, 2001

20. No authors listed: Banff schema for grading liver allograft rejection: An international consensus document. Hepatology 25: 658-663, 1997.

21. Kitamoto K, Machida Y, Uchida J, Izumi Y, Shiota M, Nakao T, Iwao H, Yukimura T, Nakatani T and Miura K: Effects of liposome clodronate on renal leukocyte populations and renal fibrosis in murine obstructive nephropathy. J Pharmacol Sci 111: 285-292, 2009

22. Ikarashi M, Nakashima H, Kinoshita M, Sato A, Nakashima M, Miyazaki H, Nishiyama K, Yamamoto J and Seki S: Distinct development and functions of resident and recruited liver Kupffer cells/macrophages. J Leukoc Biol 94: 1325-1337, 2013.

23. Stienstra R, Saudale F, Duval C, Keshtkar S, Groener JE, van Rooijen N, Staels B, Kersten S and Müller M: Kupffer cells promote hepatic steatosis via interleukin-lbeta-dependent suppression ofperoxisome proliferator-activated receptor alpha activity. Hepatology 51: 511-22, 2010.

24. Takaki H, Ichiyama K, Kog K, Chinen T, Takaesu G, Sugiyama Y, Kato S, Yoshimura A and Kobayashi T: STAT6 inhibits TGF-beta1-mediated Foxp3 induction through direct binding to the Foxp3 promoter, which is reverted by retinoic acid receptor. J Biol Chem 283: 14955-14962, 2008.

25. Zhao CQ, Li TL, He SH, Chen X, An YF, Wu WK, Zhou XH, Li P and Yang PC: Specific immunotherapy suppresses Th2 responses via modulating TIM1/TIM4 interaction on dendritic cells. Allergy 65: 986-995, 2010.

26. Rong S, Park JK, Kirsch T, Yagita H, Akiba H, Boenisch O, Haller $\mathrm{H}$, Najafian $\mathrm{N}$ and Habicht A: The TIM-1: TIM-4 pathway enhances renal ischemia-reperfusion injury. J Am Soc Nephrol 22: 484-495, 2011.

27. Zhang M, Xu S, Han Y and Cao X: Apoptotic cells attenuate fulminant hepatitis by priming Kupffer cells to produce interleukin-10 through membrane-bound TGF- $\beta$. Hepatology 53: 306-316, 2011. 
28. Chen GS and Qi HZ: Effect of Kupffer cells on immune tolerance in liver transplantation. Asian Pac J Trop Med 5: 970-972, 2012.

29. Tietjen GT, Gong Z, Chen CH, Vargas E, Crooks JE, Cao KD, Heffern CT, Henderson JM, Meron M, Lin B, et al: Molecular mechanism for differential recognition of membrane phosphatidylserine by the immune regulatory receptor Tim4. Proc Natl Acad Sci USA 111: E1463-E1472, 2014.

30. Kim HS, Lee CW and Chung DH: T cell Ig domain and mucin 1 engagement on invariant NKT cells in the presence of TCR stimulation enhances IL-4 production but inhibits IFN-gamma production. J Immunol 184: 4095-4106, 2010.

31. van Delft MA, Huitema LF and Tas SW: The contribution of $\mathrm{NF}-\kappa \mathrm{B}$ signalling to immune regulation and tolerance. Eur J Clin Invest 45: 529-539, 2015.

32. Liu LM, Liang DY, Ye CG, Tu WJ and Zhu T: The UII/UT system mediates upregulation of proinflammatory cytokines through p38 MAPK and NF- $\kappa$ B pathway in LPS-stimulated Kupffer cells. PLoS One 10: e0121383, 2015.

33. Gong XW, Xu YJ, Yang QH, Liang YJ, Zhang YP, Wang GL and Li YY: Effects of soothing liver and invigorating spleen recipes on the IKK $\beta-\mathrm{NF}-\kappa \mathrm{B}$ signaling pathway in kupffer cells of nonalcoholic steatohepatitis rats. Evid Based Complement Alternat Med 2015: 687690, 2015.

34. Li J, Gong J, Li P, Li M, Liu Y, Liang S and Gong J: Knockdown of microRNA-155 in Kupffer cells results in immunosuppressive effects and prolongs survival of mouse liver allografts. Transplantation 97: 626-635, 2014.

35. Li S, Fan Q, He S, Tang T, Liao Y and Xie J: MicroRNA-21 negatively regulates Treg cells through a TGF- $\beta 1 /$ Smad-independent pathway in patients with coronary heart disease. Cell Physiol Biochem 37: 866-878, 2015.

36. Tone Y, Furuuchi K, Kojima Y, Tykocinski ML, Greene MI and Tone M: Smad3 and NFAT cooperate to induce Foxp3 expression through its enhancer. Nat Immunol 9: 194-202, 2008.
37. Dardalhon V, Awasthi A, Kwon H, Galileos G, Gao W, Sobel RA, Mitsdoerffer M, Strom TB, Elyaman W, Ho IC, et al: IL-4 inhibits TGF-beta-induced Foxp $3^{+} \mathrm{T}$ cells and, together with TGF-beta,generates IL- $9^{+}$IL-10 $0^{+}$Foxp3(-) effector T cells. Nat Immunol 9: 1347-1355, 2008.

38. Mantel PY, Kuipers H, Boyman O, Rhyner C, Ouaked N, Rückert B, Karagiannidis C, Lambrecht BN, Hendriks RW, Crameri R, et al: GATA3-driven Th2 responses inhibit TGF-beta1-induced FOXP3 expression and the formation of regulatory T cells. PLoS Biol 5: e329, 2007.

39. Faust SM, Lu G, Marini BL, Zou W, Gordon D, Iwakura Y, Laouar Y and Bishop DK: Role of T cell TGFbeta signaling and IL-17 in allograft acceptance and fibrosis associated with chronic rejection. J Immunol 183: 7297-7306, 2009.

40. Wei J, Duramad O, Perng OA, Reiner SL, Liu YJ and Qin FX: Antagonistic nature of $\mathrm{T}$ helper $1 / 2$ developmental programs in opposing peripheral induction of Foxp3+ regulatory T cells. Proc Natl Acad Sci USA 104: 18169-18174, 2007.

41. Zhou P, Szot GL, Guo Z, Kim O, He G, Wang J, Grusby MJ, Newell KA, Thistlethwaite JR, Bluestone JA and Alegre ML: Role of STAT4 and STAT6 signaling in allograft rejection and CTLA4-Ig-mediated tolerance. J Immunol 165: 5580-5587, 2000.

42. Tang LY, Heller M, Meng Z, Yu LR, Tang Y,Zhou M and Zhang YE: Transforming growth factor- $\beta$ (TFG- $\beta$ ) directly activates the JAK1-STAT3 axis to induce hepatic fibrosis in coordination with SMAD pathway. J Biol Chem 292: 4302-4312, 2017.

This work is licensed under a Creative Commons Attribution-NonCommercial-NoDerivatives 4.0 International (CC BY-NC-ND 4.0) License. 